\title{
Critical Analysis of Nigeria's Terrorism Prevention Acts of 2011 and 2013 (Amendment) and Implications on Human Rights
}

\author{
Ifeoma E. Okoye, $\mathrm{PhD}$ \\ Assistant Professor, Department of Criminal Justice \\ Virginia State University \\ \#1 Hayden Drive, Petersburg, VA, 23806
}

\begin{abstract}
Terrorism is defined as acts of violence or threatened use of violence against a target population in an attempt to achieve political, religious or socio-economic objectives. Nigeria is presently experiencing what is considered its worst security situation since the 1967-1970 civil war due to the surge in terrorists' activities. As a result, the Nigerian government has strategically developed measures including the Terrorism Prevention Act of 2011 and its Amendment Act of 2013 to end the scourge of terrorism. This study examines the legal frameworks for the prevention of terrorism in Nigeria vis-a-vis the principles of fundamental human rights outlined in the Nigerian Constitution and the International Human Rights Laws. It significantly highlighted the lack of balance between the provisions of security and protection of human rights as evidenced in the Acts. Some irreconcilable approaches border on charges punishable by death sentences, life imprisonment, search and arrest without court warrants, detention of terrorism suspects, deprivation of citizenship, interception of communications, proscription of organizations, and excessive powers accorded to government agencies. Some provisions of the Acts are found to be incompatible with Nigeria's constitutional provisions on human rights and international human rights obligations. Among others, this study recommends the need to address excessive punishments, undue powers of government agencies, and the lack of clarity in the definition of terrorism in both the Principal and the Amendment Acts and strive to balance the protection of human rights and the provision of security in Nigeria.
\end{abstract}

Keywords: Terrorism, Human Rights, Terrorism Prevention Acts, Nigeria Constitution, International Human Rights Law

DOI: $10.7176 / \mathrm{JLPG} / 109-04$

Publication date:May $31^{\text {st }} 2021$

\section{Introduction}

According to Kofi Annan (2005: 1), the former Secretary-General of United Nations: "Terrorism is a direct attack on the core values the United Nation stands for; human rights and the rule of law, the protection of civilians; mutual respect between people of different faiths and cultures; and peaceful resolution of conflicts". Makinda (2002: 366) noted that "through the use of indiscriminate violence, terrorism has maimed and killed innocent people, threatened jobs and various social activities, and dented democratic processes of resolving conflict in society". The scourge of these terrorist activities ensued homegrown bloodshed and émigré aggression. Organized network of assaults against the population has continued to weaken the Nigerian character and its moral fiber regarding respect to human life (Onwudiwe, Tsado, Ejiogu, McGee-Cobbs \& Okoye, 2016).

The Global Terrorism Database (2020) reported over 200,000 cases of terrorism worldwide and about 5,070 terrorist attacks in Nigeria from 1970 - 2019. Terrorism has destabilized the national security, socio-economic development and democratic governance of Nigeria. The acts of terrorism have led to destruction of national and private infrastructure, kidnapping, militancy, religious and ethnic crises resulting in loss of thousands of lives and properties (Bullock, Haddow, Coppola, \& Yeletaysi, 2009; Makinda, 2002). Obviously, terrorism has a negative impact on human rights with "devastating consequences for the enjoyment of the right to life, liberty and physical integrity of victims" (Office of the United Nations, 2008, p.1). Many countries have adopted counterterrorism measures that seriously violates fundamental human rights and the rule of law such as torture, execution, denial of freedom of movement and speech, abusive interrogations, detentions without trials, repressive policies (Office of the United Nations, 2008).

In the face of these problems, the Nigerian government is required to protect its citizens through innovative approaches, especially as it relates to statutory provisions and prosecutions of those involved. Given the present spate of terrorism in Nigeria, it is essential for the country to enact and implement anti-terrorism laws in line with its constitutional provisions as well as International Human Rights and Humanitarian laws (Obiaraeri, 2012).

Nigeria's Terrorism Prevention Act of 2011 and the Terrorism Prevention Amendment Act of 2013 provided the necessary legal frameworks to counter terrorism threats in the country. Notwithstanding the extensive prohibitory provisions of these Acts in Section 1 and the penalties therefrom, terrorists have continued to unleash violence in several parts of Nigeria, especially in the North-East and North-West regions of the country leading to thousands of deaths, injuries, and wanton destruction of property. The Boko Haram terrorist 
group and its offshoot, ISIS-West Africa (ISIS-WA), have continued to carry out killings, bombings, and attacks on civilian and military targets in northern Nigeria (Global Terrorism Database, 2020). Hence, terrorist activities in Nigeria has resulted in the displacement of over 2.5 million persons, with approximately 8.5 million seeking for humanitarian assistance (U.S. Department of State, 2017). Since 2009, the terrorist group has successfully launched suicide attacks against the Nigeria Police Headquarters in Abuja, bombed United Nations headquarters in Abuja, attacked high-profile Special Anti-Robbery Squad in the nation's capital and kidnapped over 250 Chibok schoolgirls in Bornu state without apposite prosecution. Boko Haram launched its deadliest attack in 2015 by slaughtering over 2,000 people in northeastern Nigeria (National Counterterrorism Center. n.d.; CNN, 2015).

Under Section 11 of the 1999 Constitution, the National Assembly has the power to "make laws for the Federation or any part thereof concerning the maintenance and securing of public safety and public order and providing, maintaining and securing of such supplies and services as may be designated by the National Assembly as essential supplies and services." In furtherance of the above provisions, the National Assembly, with the approval of the President, adopted the "Prevention of Terrorism Act, 2011 and later amended in 2013. The Act provided measures for the deterrence, prohibition, and combatting of acts of terrorism in Nigeria and also prescribes punishments for violating any of its provisions. The Act also provided responses to the financing of terrorism in Nigeria. Consequently, the Act contains 41 sections, arranged into eight parts with schedules, listing relevant statutes. Part I defines acts of terrorism and related offences; Part II comprises provisions concerning terrorist funds and property; Part III contains mutual assistance and extradition; Part IV encompasses issues relating to information sharing on criminal matters; Part V sets out investigative processes; Part VI provides the steps for prosecuting terrorists; Part VII deals with charities linked to terrorist organizations, and lastly Part VIII contains provisions for different law enforcement authorities.

The efforts of the Nigerian legislature to create laws in response to domestic terrorism and restore security in the country is quite extensive and captures most of the legislations needed to protect the homeland from terrorism. However, without ensuring that these laws, act to protect human rights and fundamental freedoms of individuals and groups, the said efforts might seem deficient, dysfunctional, counter-productive, and of no effect (Dakas, 2013). There is a lack of balance between security and human rights protection, and the CounterTerrorism Prevention Acts and the country's constitution. From the inception, the definition of terrorism generally amounts to a breach of fundamental freedoms with the "capacity to stigmatize, de-legitimize, and dehumanize those at whom it is directed" (Nwosu, 2018: p. 77). Arguably, the Act of 2011, indirectly restrained some constitutionally guaranteed and internationally recognized human rights standards under the guise of launching war against terrorism. Consequently, the Prevention Terrorism Acts, need to be re-assessed. It is intended in this paper to exhaustively examine the extant anti-terrorism laws and proffer useful recommendations.

\section{Assessments of Some Critical Aspects of the Terrorism Prevention Acts of 2011 and 2013 (as Amended)}

\subsection{Defining Terrorism}

According to section 1 (2) (as amended),

A person or body corporate who knowingly in or outside Nigeria directly or indirectly willingly does, attempts or threatens any act of terrorism, commits an act preparatory to or in furtherance of an act of terrorism, omits to do anything that is reasonably necessary to prevent an act of terrorism, assists or facilitates the activities of persons engaged in an act of terrorism or is an accessory to any offence under the Act, participates as an accomplice in or contributes to the commission of any act of terrorism or offences under the Act, assists, facilitates, organizes or directs the activities of persons or organizations engaged in any act of terrorism, is an accessory to any act of terrorism, incites, promises or induces any other person by any means whatsoever to commit any act of terrorism or any of the offences referred to in the Act, commits an offence under the Act and is liable on conviction to maximum of death sentence.

The above Section grants broad discretion to the judge and portrays significant human rights problems. The subjection of the above-enumerated acts to a maximum of death sentence irrespective of the gravity of the offence, even in cases of mere threats, challenges the principles of proportionality and therefore susceptible to abuse, especially in the absence of a sentencing guidelines (Dakas, 2013; Nwosu, 2018). The death penalty violates the most basic of all inalienable rights; the right to life and freedom from torture and degrading treatment primarily when unjustly enforced.

Indeed, section 33 (1) of Nigeria's Constitution provides that "Every person has a right to life, and no one shall be deprived intentionally of his life, save in execution of the sentence of a court in respect of a criminal offence of which he has been found guilty in Nigeria" (Federal Republic of Nigeria Constitution, 1999). Though death penalty is allowed by the Nigerian constitution in instances where the crime has been proven beyond reasonable doubt, the Terrorism Prevention Act is replete with provisions for abuse. The death penalty is 
inherently cruel and an insult to the integrity of human life. According to Amnesty International (2002), no nation-state has the right to execute its citizens or the citizens of other nation-states. Amnesty International considers the "right to life" an inalienable right that cannot be surrendered, transferred, or abrogated, regardless of the alleged or actual offense committed by the accused or the sentenced. The United Nations (1948) also considers the "right to life" an inalienable right, proclaimed in Article 3 of the Universal Declaration of Human Rights (UDHR), adopted and proclaimed by the General Assembly of the United Nations in 1948. Article 5 further stipulates that "No one shall be subjected to torture or to cruel, inhuman or degrading treatment or punishment." Unfortunately, some countries violate the article in pursuit of their national interests.

Similarly, the death penalty is inconsistent with Section 34 (1) of the Nigerian Constitution which states that "Every individual is entitled to respect for the dignity of his person" and its subsection 1 (a) provides that "No person shall be subjected to torture or inhuman or degrading treatment" (Federal Republic of Nigeria Constitution, 1999) when in contact with the law. The death penalty is the ultimate, irreversible, cruel, inhuman, and degrading punishment that amounts to a "symptom of culture of violence" rather than a solution to criminal acts (Amnesty International, 2019). Therefore, the death penalty violates the constitutional provisions against cruel punishment, the right to dignity of human persons, and is inconsistent with the fundamental values of democratic principles. Notably, the African Union (2004) in its Article 3 (k) titled "Commitments by State Parties", urged its members to outlaw torture and other degrading and inhumane treatments such as maltreatment of terrorist suspects which are inconsistent with international human laws.

Further analysis of the Act revealed a lacuna in the provisions which are inconsistent to Part III, Article 6 of the United Nation's International Covenant on Civil and Political Rights (ICCPR). Article 6 (4) provides to the effect that "Anyone sentenced to death shall have the right to seek pardon or commutation of the sentence. Amnesty, pardon, or commutation of the sentence of death may be granted in all cases." This gap negates the role of clemency in capital offenses. It reduces the possibility of overturning court's decisions based on error and jeopardizes the capability to halt an execution warrant in the event that new evidence is discovered after the implementation of a verdict.

Establishing a pardon mechanism for death penalty cases is part of Nigeria's obligation under the United Nation's International Covenant on Civil and Political Rights (ICCPR) and its constitution. As a state party to the ICCPR, it is required that Nigeria should take statutory steps to implement the rights provided therein. According to the Black's Law Dictionary (Garner, 2009), "pardon" is defined as the act of officially forgiving certain class of persons for an offence and nullifying punishment or other legal consequences for such offence. Pardon is usually granted by the Chief Executive of a government. The power to pardon is provided under Section 175 of the 1999 Constitution of the Federal Republic of Nigeria as "prerogative of mercy" which is a constitutional power vested in the President to (a) "grant any person concerned with or convicted of any offence created by an Act of the National Assembly a pardon, either free or subject to lawful conditions"; (b) "grant to any person a respite, either for an indefinite or for a specified period, of the execution of any punishment imposed on that person for such an offence;" (c) "substitute a less severe form of punishment for any punishment imposed on that person for such an offence;" (Federal Republic of Nigeria Constitution, 1999: s. 175). Though not expressly provided, "Pardons" might be best used in cases where the death penalty is indicated as a matter of law to maximize utility for members of the society. Pardons could also solve erroneous convictions that present no legal basis for retrial and prevent innocent people from being executed.

Death penalty somewhat negates democracy and has no public safety benefit. For example, in the United States, the death penalty is illogical, in the sense that the southern states (Texas, Virginia, Oklahoma, Georgia, and Florida), which have historically executed the most number of inmates per annum, have also the highest homicide rates. In contrast, the Northeastern states, which have less than $1 \%$ of all executions, have the lowest homicide rates (Death Penalty Information Center, 2019). Studies have shown that the death penalty does not serve a deterrent measure (Tonry, 2008). Capital punishment does not deter homicides nor other felonies such as terrorism. Tonry (2008, p.280) further reiterated the assertions of Beccaria and Bentham on deterrence by stating that "certainty and promptness of punishment are more important than severity". In furtherance of the above argument, if death penalty must be enforced under this Act, the Act should be equitably applied and expanded to include the criteria that could make death penalty a deterrent measure. Such provisions should comply with the components of deterrence such as celerity and certainty. This is based on the belief that if an undesirable act is punished immediately, the individual and or others would most likely be deterred. The certainty of punishing an unlawful or undesirable act obviously exhibits the lack of profit in such action (Williams \& McShane, 2010).

Section 1 (3) (a) and (b) (as amended) describes an "act of terrorism" as,

An act which is deliberately done with malice aforethought and which may seriously harm or damage a country or an international organization; is intended or can reasonably be regarded as having been intended to unduly compel a government or international organization to perform or abstain from performing any act.

Inter alia, section 1 (3) (c) states that an act of terrorism involves or causes (i) an attack upon a person's life, 
which may cause serious bodily harm or death; (ii) kidnapping of a person. Section 1(3) (d) further provides an act of terrorism as an "act or omission in or outside Nigeria which constitutes an offence within the scope of counter-terrorism Protocols or Conventions duly ratified by Nigeria." Under section 1 (4) of the act, an act which disrupts a service, or demonstration or stoppage of work committed in pursuance of a protest does not constitute a terrorist act provided there is no intention to harm nor commit acts of terrorism.

Some provisions of the Prevention of Terrorism Act under section 1 are elusive and lack clarity in defining terrorism. Below, the author articulates some instances of the vagueness noted under Section (1) of the Act that may require further clarification.

The definition of terrorism under Section 1 (3) (a) and (b) could be interpreted to include every act in as much as there is evidence of malice to kill another, notwithstanding the objective. Despite the exculpatory provisions to safeguard civil liberties, the "intention" section of the Act, according to Cole, Smith, and DeJong (2019), is that an act is not culpable unless the mind is guilty. The proof of intention depends on whom the onus of proof lies. To secure a conviction, the prosecution must prove, not only the acts of terrorism, but that terrorism was committed deliberately with malice. This is subject to idiosyncratic interpretations with tendency to abuse. Pre-meditated crimes are considered mala in se crimes, which subjects defendants to very severe punishments. In furtherance of this analysis, a quick overview of the Organization of African Unity's (OAU) definition of terrorism also portray some loopholes especially in the area of differentiating the act of "terrorism" from other types of criminal acts. The OAU defined terrorism in its Article 1 Section 3 (a); "as any act which is a violation of the criminal laws of a state party and which may endanger the life, criminal integrity, or freedom of, or cause serious injury or death to any person, any number or group of persons or causes or may cause damage to public or private property ..." (Organization of African Unity, 2004).

Comparing the above definition from international perspective, the U.S. Department of State defines terrorism as contained in Title 22, S.2656f (d) of the U.S. code as "pre-meditated, politically motivated violence perpetrated against non-combatant targets by sub-national groups or clandestine agents, usually intended to influence an audience" (p. 1) (U.S. Department of State, 2007). Notably, Hoffman (1999: p, 43) defined terrorism as the "deliberate creation and exploitation of fear through violence or the threat of violence in the pursuit of political," economic, religious, or ideological change. Hoffman's logic was that terrorists are rational beings who can decide whether to engage in such acts of violence. In other words, terrorists' engagement in the "exploitation of fear through violence" is an aforethought or calculated move to achieve specific objectives. Therefore, terrorism is defined as ideologically-motivated violence to advance political, social, or religious goals.

The Federal Bureau of Investigations (FBI) describes terrorism as the "unlawful use of force or violence against persons or property to intimidate or coerce a government, the civilian population or any segment thereof, in furtherance of political or social objectives" (FBI, n.d.). The League of Nations Convention, 1937 (which never entered into force), defined terrorism as "All criminal acts directed against a State and intended or calculated to create a state terror in the minds of particular persons or a group of persons or the general public" (article, 1), (United Nations, 1937; Council on Foreign Relations, 2017). Similarly, the United Nations General Assembly Resolution 49/60 (United Nations December 9 9, 1994), describes terrorism as "criminal acts intended or calculated to provoke a state of terror in the general public, a group of persons or particular persons for political purposes" (para. 3). These acts of terror are criminal and unjustifiable despite the circumstances of any rational justification of violence. The U. N. provision further listed other motives such as ideological, racial, ethnic, and religious dimensions.

The term "unlawful" differentiates the above definition from the definition provided under the Prevention of Terrorism Act, 2013. The FBI, the League of Nations and the United Nations General Assembly, addressed the issue of legality by expressly emphasizing that terrorism is criminal. The act of terrorism is unlawful ab initio and should be stipulated as such. It is also crucial to differentiate terrorism from other types of crimes like armed robbery, which may also result in harm or death. However, the remarkable presence of "group objective" differentiates terrorism from other crimes. For clarity, the definition provided under the Nigerian Counterterrorism Act of 2011 (and as amended in 2013) should address terrorism as an "unlawful" act with express provision that indicates "group objectives" which is an indispensable criteria for determining terrorism.

The inclusion of kidnapping under section $1(3 \mathrm{c}$, ii) did not stipulate the form of abduction that amounts to terrorism. Kidnappers abduct for various reasons, though some kidnap to cause fear and to attract government attention like the Niger Delta Militants' and the Fulani Herdsmen. Others kidnap for ransom. In other words, the legislation could be used to prosecute ordinary kidnappers as terrorists. For clarity, the definition should be amended to explicitly conceptualize the intended nature of kidnapping to include elements of terrorism. Furthermore, the provision of Section 1(4) may be used to stifle ordinary political or labor protest primarily where such protests result in harm or destruction of properties.

Notably, section 1(3d) defines the act of terrorism as an act or omission in or outside Nigeria, which constitutes an offence within the scope of counter-terrorism protocols and conventions duly ratified by Nigeria. It is not clear if this provision is meant only for Nigerian citizens and/or foreign nationals. The broad definition 
of this section of the Act leaves considerable discretion to prosecutors. However, it is subject to the general powers of the Attorney General of the Federation to prosecute an offence committed in Nigeria and outside the country. Section 1(3d) of the Act may lead to the criminalization of individual acts carried out overseas that constitute lawful hostilities under international humanitarian laws or the local laws. For instance, the Act may also criminalize the behaviors of individuals operating under the United Nations' sanctioned use of force and acts of violent rebellion against oppressive governments, even in targeting military objectives intending to reduce civilian fatalities (Anderson, 2012).

Remarkably, section 1 of the principal Act (Terrorism Prevention Act, 2011) as further amended (Terrorism Prevention Amendment Act, 2013) included a new section 1(a) that grants the Office of the National Security Adviser the power to coordinate all security and enforcement agencies. This addition provides support to all relevant security intelligence, law enforcement agencies, and military services to prevent and combat acts of terrorism in Nigeria. The new Amendment Act of 2013 duplicated most of the massive powers of the National Security Adviser, the Inspector General of Police and the State Security Service under the Terrorism Prevention Act to the Attorney-General of the Federation by providing under section 1(a) and 2(a) (as amended) which state that "the Attorney-General of the Federation shall be the authority for the effective implementation and administration of this Act and shall strengthen and enhance the existing legal framework to ensure conformity of Nigeria's counter-terrorism laws and policies with international standards and United Nations Conventions on Terrorism." However, leaving these enormous powers with the Attorney General of the Federation without creating provisions for accountability may lead to abuse of power, official misconduct, and violation of human rights (Dakas, 2013).

\subsection{Information about acts of Terrorism}

As provided under Section 8, any person who fails to disclose to a law enforcement officer any information which he knows or believes to be of material assistance in (a) preventing the commission by another person or an organization of an act of terrorism; or (b) securing the apprehension, prosecution or conviction of another person for an offence under the Act, commits an offence under this Act and shall be liable on conviction to a minimum term of 10 years. The Act further made provisions that exempt lawyer-client privileged communication where there is reasonable ground to believe that such discussions were connected with the rules of legal advice. The purposes of such disclosure shall not be in furtherance of any unlawful purpose. However, the lacuna in this provision stems from not expressly covering other categories of privileged communications such as husbandwife privileged communications. Matrimonial communication is a form of private, privileged communication contained in section 187 of the Evidence Act of the Laws of Nigeria, which stipulates that a spouse cannot be compelled to disclose communication between them except in proceedings instituted by one of the spouses against the other (Evidence Act of Nigeria, 2011). Other forms of special privileges include privilege against self-incrimination and Priest-congregant privileged communication. As such, where interactions of these sorts occur under the unprotected categories, the in-exhaustiveness of this provision may result to unfair prosecution and subsequent conviction of any of the parties involved, thereby violating their right to fair hearing as enshrined under Section 36 (1) of the 1999 Constitution of the Federal Republic of Nigeria (CFRN, 1999).

\subsection{Proscription of Organizations}

Section 16 of the Act (as amended) made provisions against membership of a terrorist group or proscribed organizations. Its subsections provided that any person who is a member or acknowledges to be a member of a terrorist group or proscribed organization or professes to associate with others in a terrorist organization to participate or collaborate in the act of terrorism makes a person liable under the Act. A person convicted of belonging to a terrorist group or proscribed organization is liable to a minimum imprisonment of 20 years. The vast powers conferred on the government to proscribe organizations as a terrorist group is susceptible to abuse and may lead to proscribing non-governmental agencies like human rights activists as terrorist organizations or proscribing secessionist movements such as the Indigenous People of Biafra (IPOB) as terrorist organization (Adangor, 2018). Thereby labelling the struggle for independence and self-government as terrorism.

Consequently, any group that is believed to be expressly or impliedly involved in any acts that jeopardizes national interest or pose any form of security threat to the society is liable to be proscribed and could be labeled a terrorist organization. Comparing this requirement with the U.S. equivalent, the organization must engage in terrorist activity or retain the capability and intent to engage in terrorist activity or terrorism (National Commission on Terrorist Attacks upon the United States, 2010; Anderson, 2012). It is important to note that the most terrorism offences and government responses may be triggered without necessarily proving any connection to a proscribed organization as most of these terrorists operate in secrecy and small cells. The difficulty in determining membership of proscribed organizations lies in the fact that terrorists fundamentally operate in terrorist cells without necessarily belonging to any defined or formal organization. Unlike the provision of section 2 (5) of the principal Act, the Amended Act did not provide that proscribed organizations, or any person 
proven to be affected unjustly by its proscription or that has ceased to engage in the act of terrorism, may apply for de-proscription.

Notably, the proscription of organizations under the Act may encroach upon the freedoms of members or citizens who support it. Specifically, the freedom of expression and of association that is fundamentally guaranteed by Sections 39 and 40 of the Nigeria Constitution is likely to be infringed on, notwithstanding the limitations to these sections. According to Section 39 (1): "Every person shall be entitled to freedom of expression, including freedom to hold opinions and to receive and impart ideas and information without interference." Section 39 (3) also provides that nothing in this section shall invalidate any law that is reasonably justifiable in a democratic society. Section 40 (1) further provides that "Every person shall be entitled to assemble freely and associate with other persons and in particular he may form or belong to trade unions and other associations for the protection of his interests."

Proscription has implications for national security and other severe consequences that can destabilize the living conditions of persons connected to the proscribed entities (Jarvis \& Legrand, 2018). Proscription of an organization may be used as propaganda to repress a peculiar section of the population or an organization, perhaps by violent and unpleasant means (Anderson, 2012). The high tendency of abusing this section of the Act is aggravated by the fact that application for declaring an organization a proscribed entity is usually made $e x$ parte, thereby limiting the chances of presenting evidence before the court (Adangor, 2018). Given the emergency on matters of national security, courts may be persuaded to render hasty decisions that label organizations as terrorist entities, without proper investigation.

\subsection{Issuance of Warrant and Search without Warrant}

Part V of the principal Act contains the various processes involved in investigating terrorist events. Section 24 provides a warrant to search the premises of terrorist suspects and to seize and retain any relevant material. However, the principal Act under section 25 gave broad powers to law enforcement and security officers in cases of verifiable urgency to enter and search any premises or persons found in their homes. Also, they are given the power to stop, board, or search any conveyance without a search warrant if the officer reasonably believes that an offence is being committed. In the same circumstances, the law enforcement officer may also arrest, search or detain any persons if the officer has a reasonable suspicion that the suspects have committed or are likely to commit an offence under section 26 of the Act.

The issue of deciding whom to stop and search may lead to ethnic, tribal, or religious profiling because of the nature of terrorist activities in Nigeria currently, hence discriminating against a particular section of the population. The inappropriate application of the Act may contravene section 42 of the 1999 Constitution which states that,

A citizen of Nigeria of a particular community, tribe, place of origin, religion or political opinion shall not, by reason only that he is such a person be subjected either expressly by, or in the practical application of, to any law in force in Nigeria or any executive or administrative action of the Government of the Federation or the Government of a Region to disabilities or restrictions to which citizens of Nigeria of other communities, tribes, places of origin, religious or political opinions are not made subject to.

It is further provided under Section 25 that in matters of verifiable urgency and for the sake of public safety, the National Security Adviser or the Inspector General of Police may, without warrant seal up the premises of terrorist suspects while a search warrant is being sought for. This provision expressly empowers law enforcement agencies to seal up any premises without court approved search warrant. The rule is tantamount to the relegation of judicial powers and may amount to abuse and violation of privacy as enshrined in the constitution. The danger of giving such broad powers to government agencies, except where the Act did not prescribe a time limit within which the law enforcement officers must unseal the premises if the application for a search warrant is denied, may likely result in dubious decisions (Nwosu, 2018). Emergencies may warrant hasty decisions in order to protect public safety. However, the law must always seek to protect the constitutional rights of individuals as provided in the Constitution which is the summus lex terrae.

\subsection{Detention of a Suspect}

According to section 27 (1) (as amended), "a suspect may be detained under this Act for a period not exceeding 90 days subject to renewal for a similar period until the conclusion of the investigation and prosecution of the matter that led to the arrest and detention is dispensed with." The requirements of this section are contrary to section 35 of the 1999 Nigerian Constitution, specifically its subsections (4) and (5). Irrespective of the provisions of section 35 (1) (c) which states that "Every person shall be entitled to his personal liberty and no person shall be deprived of such liberty save in the following cases and in accordance with a procedure permitted by law ..." Subsection (4) also emphasized that such a person, shall be brought before a court of law within a reasonable time, not exceeding two months in the case of a person who is in custody or is not entitled to bail. 
Considering what amounts to a reasonable time, section 35 (5) provides that "a reasonable time" means "(a) in the case of an arrest or detention in any place where there is a court of competent jurisdiction within a radius of forty kilometers, a period of one day; and (b) in any other case, a period of two days or such longer period as in the circumstances may be considered by the court to be reasonable."

The above provision is also in contravention of Part III, Article 9, Section 3 of the United Nations' Universal Declaration of Human Rights of 1948. It declares that "Anyone arrested or detained on a criminal charge shall be brought promptly before a judge or other officer authorized by law to exercise judicial power and shall be entitled to trial within a reasonable time or to release." In effect, such provision of the CounterTerrorism Prevention Act may easily lead to suspects' arrests or detentions without reasonable cause nor any significant legal remedies available to the victims of such arbitrary, unlawful deprivations of liberty. Suspects are also susceptible to torture and ill-treatment in the process.

Furthermore, section 28 (1) of the Counter-Terrorism Prevention Act, 2013 (as amended) provides that "where a person is arrested under reasonable suspicion of having committed any offence under this Act, the relevant law enforcement officer or security officer may direct that the person arrested be detained in custody for a period not exceeding 48 hours from his arrest without having access to any person other than a medical officer of the relevant law enforcement or security agency or his counsel or any phone or communication gadgets." This provision contravenes section 35(2) of the Nigerian Constitution, which provides to the effect that "any person who is arrested or detained shall have the right to remain silent or avoid answering any question until after consultation with a legal practitioner or any other person of his own choice." The Act restricted access to only a medical officer or his legal counsel while limiting access to any other person of his choice. A careful observation of this provision indicates a violation of the right to fair hearing as a citizen's ability to communicate is highly restricted.

Besides, detention of persons for a period not exceeding forty-eight hours similarly contravenes Section 35 (4) (5) of the 1999 Constitution. Moreover, this section violates Nigerian Constitution under section 35 (5) that provides reasonable time "in the case of an arrest or detention in any place where there is a court of competent jurisdiction within a forty-kilometer radius, a period of one day." The provisions of section 36 (6) (a) of the Constitution guaranteed further rights to the suspects stating that "any person who is arrested or detained shall be promptly informed, in language that he understands, of the reasons for his arrest or detention." The above argument notwithstanding, section 28 (2) of the Act provides that such a direction shall not be issued unless there are reasonable grounds for its exercise to lead to consequences including tampering with evidence, physical injury, or the alerting of suspects.

According to Section 28 (4) of the Amended Act, an arrested person may on the approval of the head of the relevant law enforcement agency be placed under a house arrest and be monitored, should have no access to phones or communication gadgets, and speak only to his counsel until the conclusion of the investigation. Unless there is a court order to the effect, the provisions of Section 28 (4) are illegal, violates constitutional rights, definitely challenge the authority of the courts, and may amount to unlawful detention of suspects without legal justification. Constitutionally, the length of custody has to be reasonable, given the context. However, when law enforcement officers detain suspects without evidence for an unreasonable period and no express provision to support the detention, it amounts to constitutional violations and abuse of human rights. Holding suspects incommunicado, without access to relatives or any person of their choice (as provided in the Constitution) or the outside world, restricts suspects' ability to seek judicial remedy.

\subsection{Intelligence Gathering}

On the issue of intelligence gathering under the Act, sections 29 (as amended) requires a communication service provider to intercept and retain a specified communication; authorize law enforcement agency to install any device in such premises as to catch and keep the communication and use such for intelligence gathering. The law enforcement agency may also execute covert operations for intelligence gathering. This provision amounts to a violation of the privacy rights of citizens and the right to freedom of expression enshrined in Sections 37 and 39 of the 1999 Constitution, which may only be denied upon the order of the court. Studies show that there is prevalent abuse of powers relating to surveillance of communications by law enforcement agencies, even in highly regarded democratic countries like the United States. Such extensive powers accorded in the provision above, are likewise subject to a likelihood of abuse through unnecessary interception of citizens' private communication even in non-emergency situations. This section of the Act needs urgent examination and amendment.

\subsection{International Terrorism}

Section 9 of the principal Act extensively provided the circumstances within which a person or a group is declared an international terrorist. In subsection 1,

a person is declared suspected international terrorist by the President on the recommendation of either 
the National Security Adviser or Inspector General of Police, where he reasonably suspects that the person is or has been involved in the commission, or instigation of acts of international terrorism or is a member of, ... international terrorist group.

Subsection 3 further provides that where a person so declared possesses the Nigerian citizenship other than by birth, such a person may be deprived of his Nigerian citizenship the Constitution of the Federal Republic of Nigeria. Unquestionably, Nigerian citizens by birth are protected by the provisions of the Act; however, a citizen by either registration or naturalization is liable to forfeit or be dispossessed of his citizenship if such a person has been declared a suspected international terrorist by the President. This provision is excessive and contravenes Section 28 (1) of the 1999 Constitution which provides the condition for forfeiting of Nigerian Citizenship by naturalization or registration, where a person of that status "acquires or retains the citizenship or nationality of a country, other than Nigeria, of which he is not a citizen by birth." This provision thereby amounts to a denial of constitutional rights upon suspicion of international terrorism without due process by the court of law.

While the amended Act of 2013 addressed some of the human rights concerns prevalent in the principal Act, the requirement of reasonable suspicion of being involved or intended to be involved in the commission of the terrorist Act, or on mere suspicion or advise of government agents is still highly subjective and may present situations of abuse. This may result to violent arrests, dubious detentions innocent citizens and unsubstantiated removal of naturalized citizens from Nigeria without due process nor thorough investigations. Obviously, every law including the Prevention Terrorism Acts must align with the fundamental human rights guaranteed by various "grundnorms" in Nigeria and beyond.

\section{Implementation of the Acts and Impacts on Human Rights}

Countries facing terrorist activities resort to repressive means and arbitrary laws to quell the situations hence violating the constitutional safeguards in a democratic state. According to the United Nations and Amnesty International, Nigeria frequently deploys soldiers in aid of civil authority because of the military's perceived effectiveness in calming tumultuous situations. Although the military are usually required to carry out law enforcement functions and exercise police powers in emergency situations, such as powers of arrest and detention, they carry out this duties with utter disregard to human rights (Dakas, 2013).

According to Amnesty International, the fundamental provisions of the principal Act (Terrorism Prevention Act of 2011) are discordant with Nigeria's human rights obligations. The definition of terrorism, as provided, is elusive and overly broad. Most provisions of the principal Act unlawfully restrict fundamental human rights such as freedom of thought, conscience and religion, freedom of opinion and expression, freedom of association, and freedom of assembly. The Act's provisions on the investigation of terrorism, detention of suspects, and trial are inconsistent with the provisions of the Nigerian Constitution, International human rights and humanitarian laws. The provisions also gave lopsided powers to government agencies, thereby restricting meaningful access to competent legal remedies (as cited in Nwosu, 2018).

Notably, the Terrorism Prevention (Amendment) Act, 2013, improved on complying with human rights principles, unlike its principal Act; however, specific provisions of the Act still raise human rights concerns that need to be addressed. Research has shown that the Nigerian criminal justice system has not fully been observing procedural safeguards of fundamental rights, as pointed out in the 1999 Constitution, such as the presumption of innocence, right to a legal representative of one's choice, speedy trial, right to fair hearing, right to an interpreter, respect to freedom of speech, right to free association and freedom of movement. There are significant criticisms of certain aspects of the justice system regarding treatment of terrorist suspects. Some of them are tortured, brutally interrogated, forcefully evicted, starved, choked, unjustly detained, harassed, assaulted, sexually harassed or molested, unjustly tried or court marshalled, experienced unlawful home search, suffered displacement, and some died in incarceration without due process.

Amnesty International (2015) reported over 7,000 deaths in military detention in northeast Nigeria from 2011 - 2015 resulting from starvation, dehydration, extreme overcrowding, and denial of medical assistance. Between 2016 and 2017, at least 580 people died in the military detention facility at Giwa barracks in Maiduguri, over 4,900 people were held in extremely overcrowded cells (Amnesty International Report, 2018). Many of the suspects and their relatives were subjected to secret trials, torture, brutal treatments, and unlawful detention by the police and the State Security Service (SSS).

According to (Oyebode, n.d.), the treatment of detainees awaiting trial in Nigeria is generally pathetic. The poor treatment of detainees violates section 36 (1) of the Constitution, which asserts that "a person shall be entitled to a fair hearing within a reasonable time by a court or other tribunal established by law and constituted in such manner as to secure its independence and impartiality." Section 34 (4) expatiated on the issue of civil rights and obligations, stating that "Whenever any person is charged with a criminal offence, he shall unless the charge is withdrawn, be entitled to a fair hearing in public within a reasonable time by a court."

The defense of human rights and upholding the rule of law while countering terrorism is indeed at the heart of the United Nations Global Counter-Terrorism Strategy. Member States acknowledged that effective counter- 
terrorism measures and the protection of human rights should be balanced in all circumstances and failure to ensure this would be counter-productive (United Nations, n.d.). United Nations and Amnesty International have also frowned at the neglect of human rights as stipulated in the Nigerian Terrorism Prevention Act.

\section{Conclusion and Recommendations}

Based on the provisions of the Counter-Terrorism Acts, the law is, to a great extent, detailed on the issue of terrorism and punishments thereof, and restrictive on the subject of civil liberties. The existing laws need to be strengthened to meet the present challenges of terrorism and counter terrorism concerning fundamental human rights. As earlier mentioned, the efficacy of this war on terrorism should not be based on the substantive laws alone but also on the procedural implementation of these laws and the improvement of the law enforcement agencies whose responsibility relies on the provision of security for the country.

Justice must be enforced in all cases of terrorism through speedy trials of terrorists' suspects. The right to speedy trial is the constitutional right of the accused person, which prevents undue and oppressive incarceration before trial. Nigeria can achieve speedy trials if the legislature can consider creating special courts to try terrorism cases to avoid the backlogs and unnecessary delays attendant in the country's judicial processes and procedures. Special courts must strive to follow due process and maintain civil liberties in legal proceedings. Furthermore, the government should consider reducing the excessive powers of the National Security Adviser, the Inspector General of the Police, the Attorney-General and other law enforcement officers that may have contributed to undue delays in prosecuting of terrorist suspects.

On the issue of death penalty under section 1 (2) of the amended Act, it is necessary that the law makers consider the efficacy of death penalty in a democratic setting. Studies have shown that death sentence does not really serve a deterrent measure to discourage crimes like terrorism, it rather negates democracy. Several literature and legal provisions reviewed in this paper posited that death penalty is inhumane, a usurpation of fundamental human rights, an incitement of violence and irreversible and therefore must be replaced with imprisonment.

Proscription of organizations as provided in the Act requires clarity especially in the area of specific criteria that qualify an organization for proscription. The legislators may consider some proscription criteria such as those articulated in the literature according to Anderson (2012): the nature and scale of an organization's activities; the specific and active threat that it poses to Nigeria, its nationals within and abroad; the extent of the organization's presence and nexus in Nigeria; the necessity to support other members of the international community in the global war against terrorism; proscribing an organization must be proportional to protecting the public from terrorism. Nigeria should adopt a cautious approach in proscribing organizations as practiced in countries like Canada, United Kingdom, and Australia. In furtherance of its section 16 (as amended), the Act should be modified to reinstate the provisions of the Principal Act on de-proscription of organizations and persons who no longer participates in acts of terrorism.

The Act should expand its provisions under section 26 on intelligence gathering to include information sharing between members of the community and the law enforcement agencies, not just from communication service providers. Mostly, there should be improved intelligence gathering capability by the various security outfits in order to effectively tackle terrorism. This requires deepened training, particularly in areas of human intelligence, forensic science, data gathering, storage and retrieval, and broad information management. Nigerian police should understand and imbibe the tenets of community policing as this would help them to establish a symbiotic relationship with the community. Community policing philosophy entails sharing of information between members of the community and police officers, activates interactive partnership in dealing with crime problems, promotes problem-solving, and stimulates effective communications with members of the public (United States Department of Justice, 2014). Community policing utilizes information gained from citizens to help define the parameters of community problems like terrorists or kidnappers' hideout, and their modus operandi.

To further ensure fundamental rights of suspects, fringe suspects who pose no risk to public safety, need not be kept in detention more than constitutionally necessary. In order to clarify the provisions of section 25 (1) (c), consideration should be given to elaborating the law to include the criteria for deciding whom to stop and search. Law enforcement officers must avoid tribal, racial, or religious profiling but may focus searches on the basis of evidence. Lawmakers generally need to overhaul some particular sections of the Act earlier pointed out to comply with the provisions of the Nigerian Constitution. Notably, Section (1) (1) of the 1999 Nigerian Constitution outrightly stated that "This constitution is supreme and its provisions shall have binding force on all authorities and persons throughout the Federal Republic of Nigeria. To further reiterate the supremacy of the Constitution, section (1) (3) provided that "if any other law is inconsistent with the provisions of this constitution, this constitution shall prevail and that other law shall to the extent of the inconsistency be void." These constitutional provisions are to the effect that any provisions of the Terrorism Prevention Act, 2011, and its Amendment of 2013 that is inconsistent or contravenes the provisions of the constitution shall be null and void. 
Finally, the Nigerian government must enthusiastically uphold international human rights standards in its war against terrorism. When the government seeks to limit fundamental freedoms, it should do so in a manner that is both justifiable and proportionate. The Nigerian government should also take lessons from other countries of the world that have battled terrorism and succeeded to a great extent. The government should also consider conciliatory approaches or negotiations via restorative justice in its strategies. Overall, Nigeria's government can control the fog of terror by limiting access to funding and the availability of weapons of war by Boko Haram and other rising insurgent groups.

The preceding recommended counterterrorism strategies are not exhaustive, hence the need for further research to identify other effective legal approaches for addressing the terrorism phenomenon with respect to fundamental human rights. Future research also need to investigate the effects of government use of micropolicies such as surveillance techniques, restriction on movements, curfews and use of special courts on human rights. Additionally, research and analysis should critically examine how the government could efficiently adopt other policies that specifically target various terrorists' weapons of terror such as rape, infanticide and genocide of an ethnic group without violating constitutional rights.

\section{References}

Adangor, Z. (2018). Proscription of the Indigenous People of Biafra (IPOB) and the Politics of Terrorism in Nigeria. The Journal of Jurisprudence and Contemporary Issues, 10 (1); 143-156

African Union. (2004). Protocol to the OAU Convention on the Prevention and Combating of Terrorism Adopted by the Third Ordinary Session of the Assembly of the African Union, Addis Ababa, 8 July, 2004.

Amnesty International. (2015). Stars on their shoulders. Blood on their hands. War crimes committed by the Nigerian military. Retrieved www.amnesty.org/download/Documents/AFR4416572015ENGLISH.PDF

Amnesty International Report. (2018). The State of the World's Human Rights. Retrieved from https://www.amnesty.org/download/Documents/POL1067002018ENGLISH.PDF

Amnesty International. (2019). Death Penalty. Retrieved from https://www.amnesty.org/en/what-we-do/deathpenalty/

Amnesty International U.S.A. (2002). United States of America arbitrary, discriminatory, and cruel: An aidememoire to 25 Years of judicial killing, AI Index: AMR 51/003/2002. New York, NY: Amnesty International Publications.

Anderson, D. Q. C. (2012). The Terrorism Acts in 2011: Report of the independent Reviewer on the operation of the Terrorism Act 2000 and part 1 of the Terrorism Act, 2006. Retrieved from http://www.nationalarchives.gov.uk/doc/open-government-licence

Annan, K. (March 10, 2005). Kofi Annan's keynote address to the closing plenary of the International Summit on Democracy, Terrorism and Security. United Nations Secretary-General. Retrieved from https:/www.un.org/sg/en/content/sg/speeches/2005-03-10/kofi-annan\%E2\%80\%99s-keynote-addressclosing-plenary-international-summit

Bullock, J., Hadddow, G., Coppola, D., \& Yeletaysi, S. (2009). Introduction to Homeland Security. (3 ${ }^{\text {rd }}$ ed.). Massachusetts: Elsevier Inc.

CNN. (January 12, 2015). 2,000 feared killed in 'deadliest' Boko Haram attack in Nigeria. Retrieved from https://www.cnn.com/2015/01/09/africa/boko-haram-violence/index.html

Cole, G. F., Smith, C. E., \& DeJong, C. (2019). The American System of Criminal Justice. $16^{\text {th }}$ Edition. Boston, MA: Cengage Learning Inc.

Council on Foreign Relations. (2017). UN General Assembly Resolution 3034 (XXVII). Measures to Prevent Terrorism. Dec 1972. [Online] Available: http://www.cfr.org/terrorism-and-the-law/un-general-assemblyresolution-3034xxvii-measures-prevent-terrorism/p24793

Dakas, C. D. (2013). Nigeria's Anti-Terrorism Laws and Practices: The Imperative of Mainstreaming Human Rights into Counter-Terrorism Administration. Retrieved from ncicc.org.ng/.../Dakas-Terrorism-AntiTerrorism\%20Laws\%20and\%20Pr

Death Penalty Information Center. (2019). Facts about the Death Penalty. Retrieved from https://files.deathpenaltyinfo.org/legacy/documents/FactSheet.pdf

Evidence Act of Nigeria. (2011). Communications during Marriage. Retrieved from https://www.refworld.org/pdfid/54f86b844.pdf

Federal Bureau of Investigation, (n.d.). Terrorism 2002-2005. Retrieved from http://www.fbi.gov/statsservices/publications/terrorism-2002-2005

Federal Republic of Nigeria Constitution. (1999). Retrieved from https://publicofficialsfinancialdisclosure.worldbank.org/sites/fdl/files/assets/law-libraryfiles/Nigeria_Constitution_1999_en.pdf

Garner, B. A. (2009). Black's Law Dictionary. $9^{\text {th }}$ Edition. Thomson Reuters: Eagan MN 
Global Terrorism Database. (2020). Retrieved from https:/www.start.umd.edu/gtd/about/

Hoffman, B. (1999). Inside terrorism. London: Victor Gollancz.

Jarvis, L. \& Legrand, T. (2018). The Proscription or Listing of Terrorist Organizations: Understanding, Assessment, and International Comparisons. Terrorism and Political Violence, 30 (2), 199-215

Makinda, S. M. (2002). Terrorism, counter-terrorism and norms in Africa. African Security Review. 15(3), 19-31

National Commission on Terrorist Attacks upon the United States, 9/11 Report, para 12.3.

US Proscription test: http:/www.state.gov/i/ct/rls/crt/2010/170264.htm

National Counterterrorism Center. (n.d.). Boko Haram. Retrieved from https://www.dni.gov/nctc/groups/boko haram.html

Nwosu, U. W. (2018). Anti-terrorism Legislation and Human Rights - An Appraisal of the Nigerian terrorism (prevention) act, 2011. International Journal of Peace and Conflict Studies (IJPCS), Vol. 5, (1).

Obiaraeri, N.O. (2012). Still on Human Rights. Owerri: Global Press Ltd.

Office of the United Nations: High Commissioner for Human Rights. (2008). Human Rights, Terrorism and $\begin{array}{lllll}\text { Counterterrorism. } & \text { Factsheet } & \text { No. } & 32 . & \text { Retrieved }\end{array}$ https://www.ohchr.org/documents/publications/factsheet32en.pdf

Onwudiwe, I. D., Tsado, L., Ejiogu, K. U., McGee-Cobbs, R. E. \& Okoye, I. E. (2016). In Defense of the Nigerian Homeland. African Social Science Review, vol 8 (1), 87 - 115

Organization of African Unity (1999). Convention on the Prevention and Combating of Terrorism. Adopted on 1 July1999, entered into force 6 December 2002.

Oyebode, A. (n.d.). Legal Responses to the Boko Haram challenge: An Assessment of Nigeria's Terrorism (Prevention) Act, 2011. Retrieved from www.unilag.edu.ng/opendocnew.php?

Terrorism Prevention Act. $\quad$ (2011). Retrieved from http://www.vertic.org/media/National\%20Legislation/Nigeria/NG_Terrorism_Prevention_Act_2011.pdf

Terrorism Prevention Act. (2013). Retrieved from https://placng.org/i/wp-content/uploads/2019/12/TerrorismPrevention-Amendment-Act-2013.pdf

Tonry, M. (2008). Learning from the limitations of deterrence research. Crime and Justice, 37(1), $279-311$.

United Nations. (1937). Convention for the Prevention and Punishment of Terrorism. United Nations Office at Geneva Library. Retrieved from https://www.wdl.org/en/search/?institution=united-nations-office-genevalibrary

United Nations. (n.d). International Covenant on Civil and Political Rights (ICCPR). Retrieved from https://www.ohchr.org/en/professionalinterest/pages/ccpr.aspx

United Nations. (2001). Resolution 1373, 2001. Retrieved from http://unispal.un.org/UNISPAL.NSF/0/392A001F254B4B9085256B4B00708233

United Nations. Universal Declaration of Human Rights. Adopted and proclaimed by the General Assembly of the United Nations December 10, 1948. Retrieved from https:/www.un.org/en/universal-declarationhuman-rights/

United Nations. (n.d.). United Nations Global Counter-Terrorism Strategy. Retrieved from

http://www.un.org/terrorism/human_rights.shtml

United States Department of Justice. (2014). Community Policing Defined. Retrieved from https://cops.usdoj.gov/RIC/Publications/cops-p157-pub.pdf

United States Department of State. (n.d.). Chapter 38 - Department of State. Retrieved from https://uscode.house.gov/view.xhtml?path=/prelim@title22/chapter38\&edition=prelim

United States Department of State. (July 31, 2012). Country Reports on Terrorism 2011 - Nigeria, Retrieved from https://www.refworld.org/docid/501fbca9c.html

United States Department of State. (2017). Country Reports on Terrorism 2017. Retrieved from https://www.state.gov/reports/country-reports-on-terrorism-2017/

Williams, F. P., \& Mcshane, M. D. (2010). Criminological theory. (5 $5^{\text {th }}$ ed). New Jersey: Pearson Education Inc. 